\title{
Affecting Factors on Entrepreneurial Orientation in the Industry
}

\author{
Nour-Mohammad Yaghoubi, Maryam Naroei \\ University of Sistan and Baluchestan, Zahedan, Iran
}

\begin{abstract}
In the present age, entrepreneurship at the organizational level and entrepreneurial orientation at the individual level can be considered as competitive advantage in a new age. This study examines the affecting factors on entrepreneurial orientation in a sample of 248 employees in the industry. This article considered employees' entrepreneurial orientation as an dependent variable and emotional and organizational intelligences, as independent variables, which may be effected on entrepreneurial orientation. The results of data analysis by LISREL show that employees' willingness to act entrepreneurially increases when they have high emotional and organizational intelligences.
\end{abstract}

Keywords: entrepreneurial orientation, emotional intelligence, organizational intelligence

\section{Introduction}

Today's business environments are complex and dynamic characterized by rapid, substantial discontinuous changes. In response to these challenges, firms must follow an entrepreneurial strategic posture and encourage their organizational members to act entrepreneurially (Brundin, Patzelt, \& Shepherd, 2007). Many authors have singled out corporate entrepreneurship as an organizational process that contributes to firm survival and performance (Lumpkin \& Dess, 1996; Miller, 1983; Zahra, 1993b). In short, these authors argue that entrepreneurial attitudes and behaviors are necessary for firms of all sizes to prosper and flourish in competitive environments. As a result of these sentiments, a growing body of literature is evolving to help firms understand the organizational processes that facilitate entrepreneurial behavior (Lumpkin \& Dess, 1996; Zahra, 1991). Individual and organizational intelligences are conceptualized as being functionally similar, i.e., as purposeful information processing that enables adaption to environmental demands. Organizational intelligence, however, is a social outcome and is related to individual intelligence by mechanisms of aggregation, cross-level transference, and distribution (Glynn, 1996). Unfortunately, no study has focused specifically on the effect emotional and organizational intelligences on entrepreneurial orientation. Instead, the studies that have examined the organizational characteristics that facilitate entrepreneurial behavior have looked at a broad array of variables and have not provided extensive insight about the impact of emotional and organizational intelligences on entrepreneurial orientation.

Nour-Mohammad Yaghoubi, Ph.D., Department of Management, School of Management and Accounting, University of Sistan and Baluchestan.

Maryam Naroei, Master of Public Administration, Department of Management, School of Management and Accounting, University of Sistan and Baluchestan.

Correspondence concerning this article should be addressed to Nour-Mohammad Yaghoubi, University of Sistan and Baluchestan, Zahedan 9816745685, Iran. E-mail: yaghoobinor@yahoo.com. 


\section{Review of Literature}

\section{Entrepreneurial Orientation (EO)}

The essential act of entrepreneurship is new entry. New entry can be accomplished by entering into new or established markets with new or existing goods or services. New entry is the act of launching a new venture, either by a start-up firm, through an existing firm, or via “internal corporate venturing” (Burgelman, 1983). EO involves a willingness to innovate to rejuvenate market offerings, take risks to try out new and uncertain products, services, and markets, and be more proactive than competitors to ward new marketplace opportunities (Miller, 1983; Zahra, 1993b). Miller (1983) summarizes the characteristics of an entrepreneurial firm. An entrepreneurial firm is one that engages in product market innovation, undertakes somewhat risky ventures, and is first to come up with proactive, innovations, beating competitors to the punch (Miller, 1983). EO refers to a firm's strategic orientation, capturing specific entrepreneurial aspects of decision-making styles, methods, and practices. As such, it reflects how a firm operates rather than what it does (Lumpkin \& Dess, 1996). Lumpkin and Dess indicates that EO is a combination of five dimensions: autonomy, innovativeness, risk taking, proactiveness, and competitive aggressiveness, which have been useful for characterizing and distinguishing key entrepreneurial processes, that is, a firm's entrepreneurial orientation. Several researchers have agreed that EO is a combination of the three dimensions: innovativeness, proactiveness and risk taking (Miller, 1983; Hisrich, 2001). This study focuses on conceptualization suggested by Miller (1983) and Hisrich (2001).

\section{Emotional Intelligence (EI)}

Mayer and Salovey defined emotional intelligence as the ability to perceive emotions, to access and generate emotions so as to assist thoughts, to understand emotions and emotional and intellectual growth. They (1989, 1990) argued that there is a set of three conceptually related mental process-appraising and expressing emotions in the self and others, regulating emotions in the self and others, and using emotions in adaptive ways-involving emotional information (Carmeli, 2003; Gardner \& Stugh, 2002). Bar-On's (2000) non-cognitive model defines emotional intelligence as an array of non-cognitive capabilities, competencies and skills that influence one's ability to succeed in coping with environmental demands and pressures. Bar-on has operationalized this model according to 15 conceptual components that pertain to five specific dimension of emotional and social intelligence, these are: intrapersonal emotional intelligence; interpersonal emotional intelligence; adaptability; stress management and general mood (Gabel \& Cerdin, 2005; Gardner \& Stugh, 2002). This study focuses on conceptualization suggested by Goleman (1995, 1998a). A definition provided by Goleman that "The capacity for organizing our own feeling and those of others, for motivating ourselves, and for managing emotions will in ourselves and in our relationship” (Goleman, 1998b; Rahim \& Minors, 2003). Goleman (1998b) suggests that EQ at work is a multidimensional construct consisting of five components, such as: self-awareness, self-regulation, motivation, empathy, social skills (Goleman, 1998a).

\section{Organizational Intelligence (OI)}

Organizational intelligence is a function of five cognitive subsystems: organizational structure, culture, stakeholder relationship, knowledge management and strategic processes (Halal, 2006). Simic (2005) defines organizational intelligence as an intellectual capacity to solve problems within an organization. The core of this definition is getting together of human being along with technical capacity in problem solving process (Simic, 2005; Cakir \& Ada, 2008). Albrecht (2003) explains organizational intelligence as the collective sum of individual intelligences. He (2003, 2009) claims OI has seven dimensions those of which are strategic vision, 
shared fate, appetite for change, heart, alignment and congruence, knowledge deployment, performance pressure (Albrecht, 2009). This study focuses on conceptualization suggested by Albrecht (2003).

\section{Research Model}

With review of literature, the conceptual model for research is selected and showed in Figure 1. In this article, we considered employees' entrepreneurial orientation (at the organizational level) as an dependent variable and emotional and organizational intelligences, as independent variables, which may be associated with EO. In other words, this study was conducted to examine the relationship between EI and OI with EO. Therefore, below are research hypotheses:

H1: There is significant relationship between EI with EO.

H2: There is significant relationship between OI with EO.

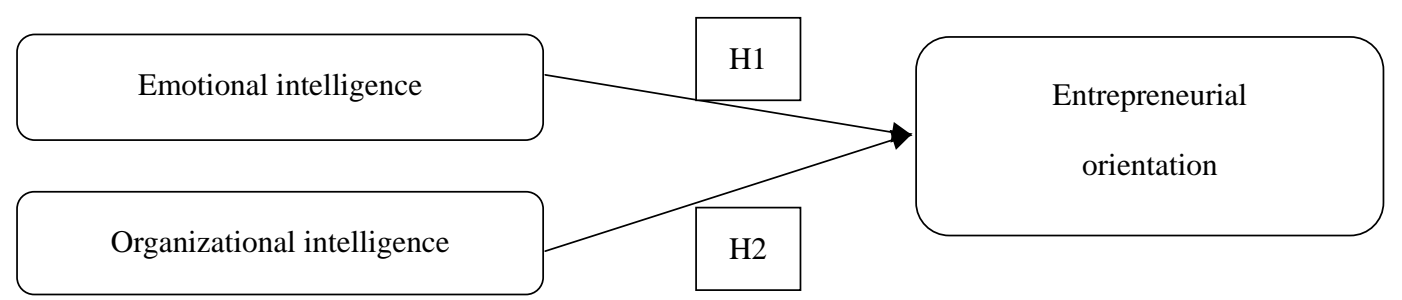

Figure 1. Research conceptual model.

\section{Results}

Statistical sample was 248 of employees in the industries that selected on Simple Random Sampling. Emotional intelligent questionnaire was designed by Goleman in 1998. It has 25 questions in 5 indexes included in self-awareness, self-regulation, motivation, empathy and social skills. Its reliability was 0.87 . Organizational intelligent questionnaire was designed by Albrecht in 2003. It has 49 questions in 7 indexes included in strategic vision, shared fate, appetite for change, heart, alignment and congruence, knowledge deployment, performance pressure. Its reliability was 0.96 . We used an 18 -item scale to measure of entrepreneurial orientation. The scale contains items that measure on employee's orientation toward innovation, risk taking and proactiveness, which are the dimensions of entrepreneurial orientation. Its reliability was 0.91 . The participants $(N=248)$ were male (65.3\%) and female (34.7\%). According to results, they were $12.5 \%$ supervisor, $10.9 \%$ expertise, $17.7 \%$ employees and $58.9 \%$ worker. Their degree of education was $78.9 \%$ below bachelor and $19.8 \%$ with bachelor.

\section{Hypotheses Test}

In test target hypotheses, first, software output represents suitable of fitted structural model for testing hypotheses (amount $\frac{\mathrm{x} 2}{d f}$ is less than three and RMSEA $=0.077$, GFI $=0.95$, AGFI $=0.91$ show a suitable fit of structural equation modeling). In other words, observed data to a large are based on the research conceptual model. Figure 2 shows the research structural model in the state of standard estimates.

Figure 3 shows obtained significant coefficients and parameters of structural models of emotional and organizational intelligences and entrepreneurial orientation. When obtained coefficients are significant that the value of their significant test larger of the number 1.96 and smaller of number -1.96 , as seen significant coefficient between emotional intelligence and entrepreneurial orientation is equal to 3.93 and also between organizational intelligence and entrepreneurial orientation is equal to $9 / 65$. Therefore main hypotheses of the study are confirmed. 


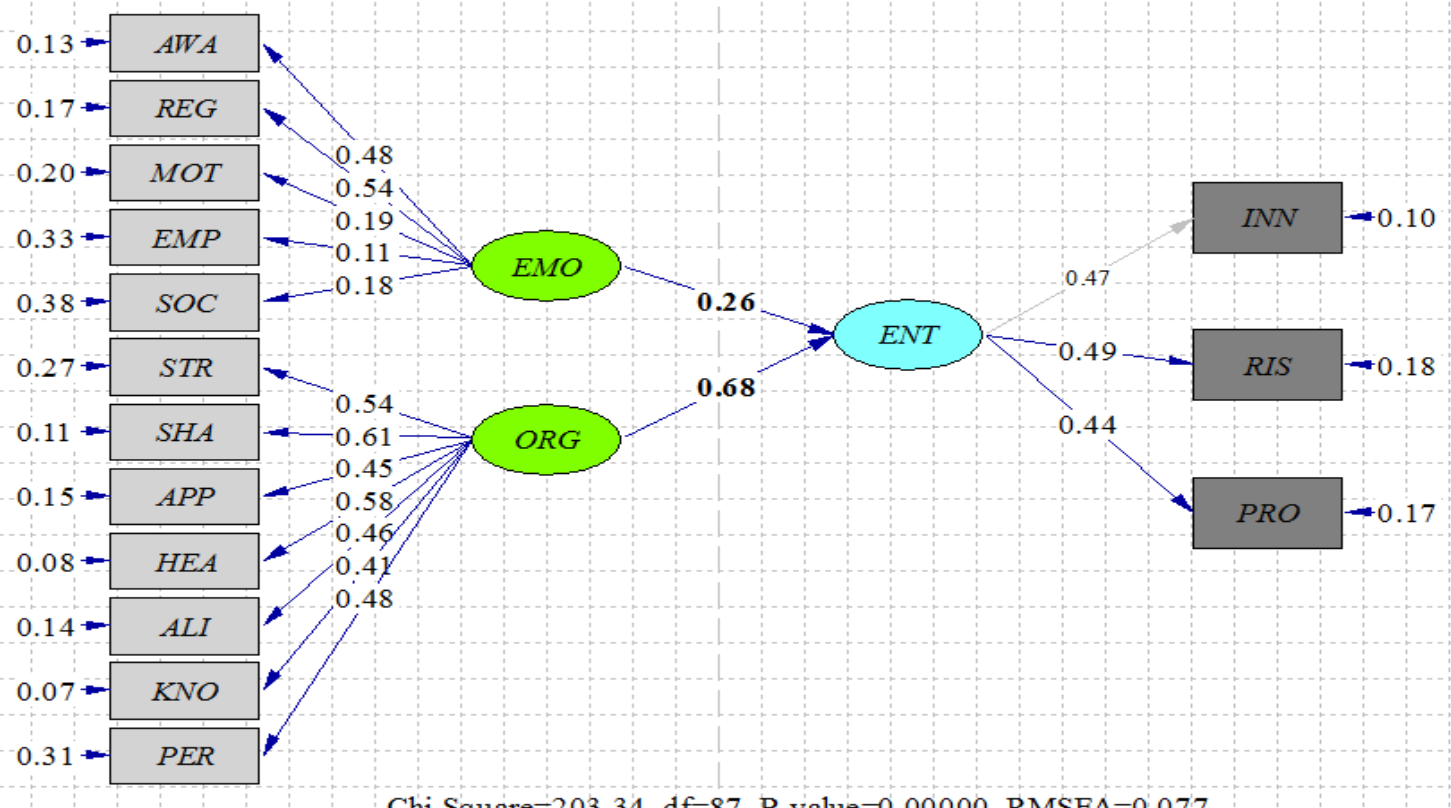

Chi-Square $=203.34, \mathrm{df}=87, \mathrm{P}$-value $=0.00000, \mathrm{RMSEA}=0.077$

Figure 2. Structural equation modeling for confirming main hypotheses in the state of standard estimates. EMO: Emotional intelligence; AWA: Self awareness; ORG: Organizational intelligence; KNO: Knowledge management; REG: Self-regulation; MOT: Motivation; STR: Strategic vision; PER: Performance pressure; EMP: Empathy; SOC: Social skills; SHA: Shared fate; ENT: Entrepreneurship; APP: Appetite for change; HEA: Heart; ALI: Alignment and congruence; INN: Innovation; RIS: Risk-taking PRO: Pro-activeness.

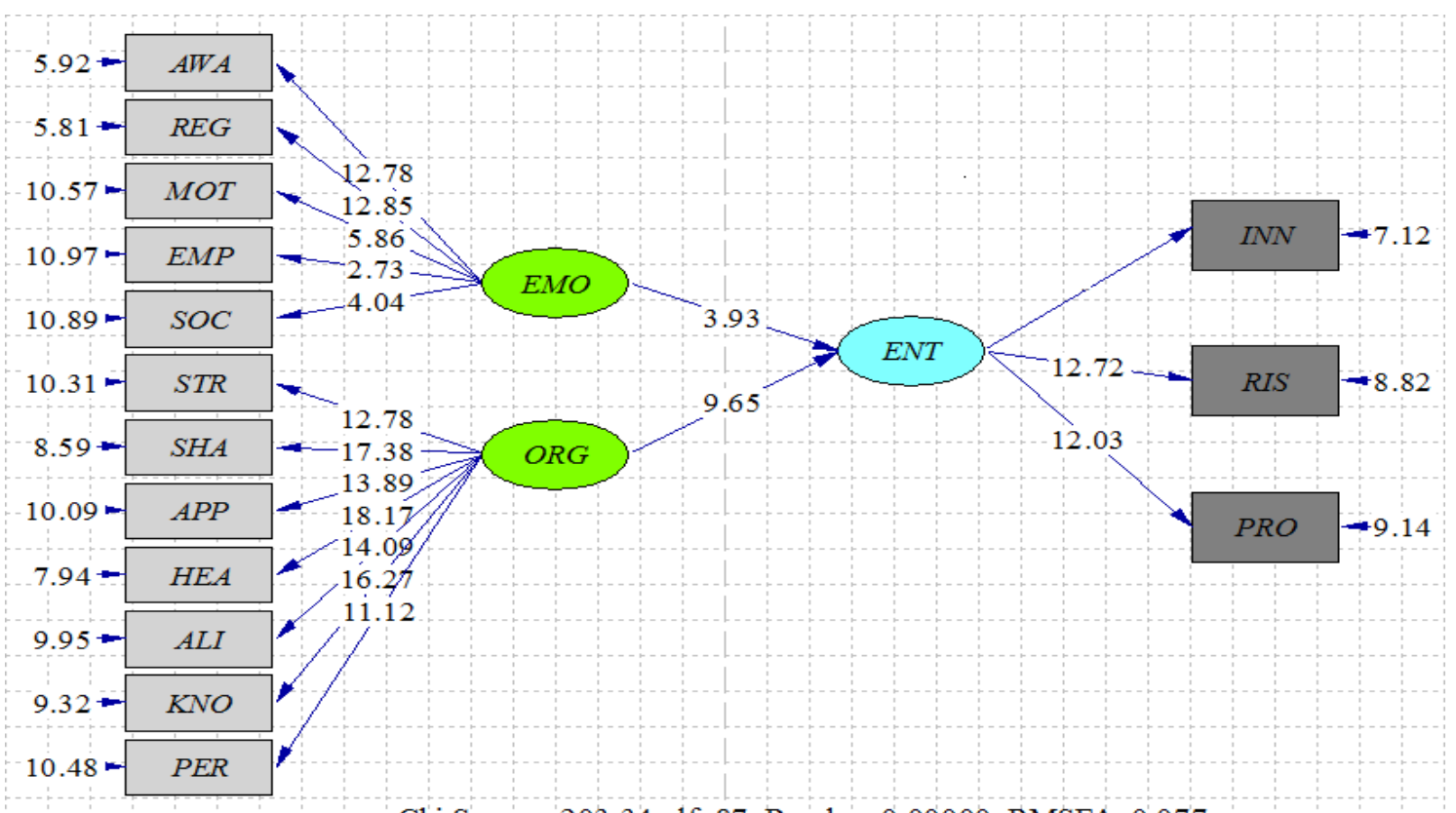

Chi-Square $=203.34, \mathrm{df}=87, \mathrm{P}$-value $=0.00000, \mathrm{RMSEA}=0.077$

Figure 3. Structural equation modeling for confirming main hypothesis in the state of significant parameters. EMO: Emotional intelligence; AWA: Self awareness; ORG: Organizational intelligence; KNO: Knowledge management; REG: Self-regulation; MOT: Motivation; STR: Strategic vision; PER: Performance pressure; EMP: Empathy; SOC: Social skills; SHA: Shared fate; ENT: Entrepreneurship; APP: Appetite for change; HEA: Heart; ALI: Alignment and congruence; INN: Innovation; RIS: Risk-taking PRO: Pro-activeness. 


\section{Conclusion}

Brundin et al. (2007) demonstrates that emotional displays of manager have a significant impact on the decision policies of employees. Specifically, displays of confidence and satisfaction with an entrepreneurial project enhance the employee's willingness to act entrepreneurially, whereas displays of frustration, worry, and bewilderment, respectively, diminish it. This finding is in line with Mayer and Salovey (1997) and George (2000) who argue that emotionally intelligence managers are able to use emotions in order to manipulate cognitive processes among employees. Emotions direct attention and the displayed emotions of managers may put employees in good or bad moods (Pugh, 2001). The emotional labor literature indicates that service worker's displayed emotions can influence the behavior of customers (Rafaeli \& Sutton, 1987). Nasabee, Jahanee and Safarpur (2009) demonstrate that creativity and intelligence are the superior characteristics which are put in each organization member. Organizational intelligence is a social outcome and is related to individual intelligence. So its root as creativity is located in mind. This similarity upholds relationship between OI and creativity. The results show that emotional and organizational intelligences are effect on entrepreneurial orientation. In others words, people with high emotional intelligence are innovative, proactive and risk-taker. With the help of organizational intelligence, the organization can pay to diversity funding, programs and performance analysis, development perspectives and design appropriate strategies. Organizational intelligence is defined as talent and capacity an organization on mental power and focus on this power in achieving the mission of organization. Organizational intelligence should be regarded managers, which means that dimensions of OI about their organization, should be measured, reviewed and periodically appraised.

\section{References}

Albrecht, K. (2003). The power of minds at work: Organizational intelligence in action. New York: Amacon.

Albrecht, K. (2009). Organizational intelligence and knowledge management: Thinking outside the silos. Retrieved from http://www. Karl Albrecht.com

Bar-On, R. (2000). Emotional and social intelligence. In R. Bar-on, \& J. D. A. Parker (Eds.), The hand book of emotional intelligence. San Francisco, C.A.: Jossey Bass.

Brundin, E., Patzelt, H., \& Shepherd, D. A. (2007). Managers emotional displays and employees' willingness to act entrepreneurially. Journal of Business Venturing, 23, 221-243.

Burgelman, R. A. (1983). Corporate entrepreneurship and strategic management: Insights from a process study. Management Science, 29(12).

Cakir, R., \& Sukru, A. (2008). Can the organizational intelligence be developed in schools by in service training? (Giresun Mustafakemal Primary School Case). World Applied Science Journal, 4(1), 24-30.

Carmeli, A. (2003). The relationship between emotional intelligence and work attitudes, behavior, and outcomes. Journal of Managerial Psychology, 18(8), 788-813.

Gabel, R., Dolan, S., \& Cerdin, J. (2005). Emotional intelligence predicator of cultural adjustment for success in global assignment. Career Development International, 10(5), 375-395.

Gardener, L., \& Stugh, C. (2002). Examining the relationship between leadership and emotional intelligence in senior level managers. Leadership and Organization Development Journal, 23(2), 68-78.

Glynn, M. A. (1996). Innovate genius: A framework for relating individuals and organization intelligences to innovation. The Academy of Management Review, 21(4), 1081-1111.

Goleman, D. (1995). Emotional intelligence. New York: Bantam Books.

Goleman, D. (1998a). What makes a leader? Harvard Business Review, 76(6), 93-102.

Goleman, D. (1998b). A working with the emotional intelligence. A Bantam Book.

Halal, W. E. (2006). Organizational intelligence. Melcurm publishing Ltd..

Hisrich, A. (2001). Contextual influence on the corporate entrepreneurship-performance relationship: A longitudinal analysis. 
Journal of Business Venturing, 10.

Lumpkin, G., \& Dess, G. G. (1996). Clarifying the entrepreneurial orientation construct and linking it to performance. Academy Management Review, 21(1), 135-172.

Miller, D. (1983). The correlates of entrepreneurship in three types of firms. Management Science, 29(7), 770-791.

Nasabee, N., Jahanee, J., \& Safarpur, A. (2009). Relationship of organizational intelligence and personal creativity in Shiraz university of Medical Science in 2008. World Applied Sciences Journal, 6(11), 1481-1488.

Pugh, S. D. (2001). Service with a smile: Emotional contagion in the service encounter. Academy of Management Journal, 44(5), 1018-1027.

Rafaeli, A., \& Sutton, R. I. (1987). Expression of emotion as part of the work role. Academy of Management Review, 12 , 23-37.

Rahim, M. A., \& Minors. (2003). Effects of emotional intelligence on concern for quality and problem solving. Managerial Auditing Journal, 18(2), 150-155.

Simic, I. (2005). Organizational learning as a component of organizational intelligence. Information and Marketing Aspects of the Economically, 189-196.

Zahra, S. A. (1991). Predicators and financial outcomes of corporate entrepreneurship: an exploratory study. Journal of Business Venturing, 6(4), 285-295.

Zahra, S. A. (1993a). A conceptual model of entrepreneurship as firm behavior: A critique and extension. Entrepreneurship Theory and Practice, 16, 1-17.

Zahra, S. A. (1993b). Environment, corporate entrepreneurship and financial performance: A taxonomic approach. Journal of Business Venturing, 8(4), 319-340. 